\title{
How students use social networks in education?
}

\author{
Artem Feshchenko ${ }^{1 \mathrm{a}}$ \\ ${ }^{1}$ Tomsk State University, Tomsk 634050, Russian Federation
}

\begin{abstract}
The aim of this study is analysis of the use of social networks (SN) by Russian students in training. The study analyzed the results of the survey respondents from 25 universities of the Russian Federation (375 participants). Results of the study showed that $95 \%$ of students use SN in education, $5 \%$ refuse them. Students spend about $24 \%$ of their time to SN for the purpose of learning. Remaining time they spend on entertainment (41\%), finding useful information (28\%) and other (7\%). Distribution of training time takes students: $35 \%$ - in the classroom with a teacher, $22 \%$ using a variety of ICT (not including SN and LMS), 21\% - extracurricular work without ICT, 15\% - in SN, 7\% - in LMS. Social networks are the de facto space for learning, and it's happening at the initiative of the students themselves. And if the teacher offers students interact via the network in the course, the students' attention more switches from entertainment to education.
\end{abstract}

Keywords: E-learning; social networks; ways of learning; LMS.

\section{Introduction}

At the present time, higher education in Russia is undergoing a process of rapid and intensive implementation of e-learning technologies. The strategy and the basic principles of this process are stated in the Russian legislation on education. Nevertheless, each university determines its own tactics of online learning tools implementation into its educational environment. In general, the formation of a virtual learning environment (VLE) at the university happens to the use of learning management systems (LMS). But the growing popularity of Web 2.0 services and social media among Internet users, including students, forms personal learning environment (PLE) alongside with VLE in education. The integration of VLE and PLE is becoming a crucial task in the elaboration of integrated development projects of e-learning at the university. The task solution is impossible without the analysis of special aspects of various e-learning tools used by students and teachers and identification of their preferences.

\footnotetext{
a Corresponding author: fav@ido.tsu.ru
} 
In our previous study, «E-learning in the evaluation of students and teachers: LMS or social networks?» [1], we tried to study these processes and found out that teachers equally evaluate LMS and social networking in education, and students evaluate social networks higher than LMS. In the course of this study, we tried to examine Russian students' peculiarities of social networking usage in education in more detail. The choice of research methods is due to studying the experience of foreign works on the use of social networks in teaching of students [2, 3 and 4], as well as the results of the implementation of social media and networking technologies into the VLE of Tomsk State University $[5,6]$.

\section{Method}

Survey materials on the topic of "Technologies of e-learning at the university" (MayOctober 2014) are used in this study. 375 students from 25 universities of the Russian Federation took part in the survey. The following methods are used in the research: questionnaire, statistical data processing, content analysis and comparative analysis of the results. Google Forms were used to collect data, and specialized software «Statistica v6.1.Ru» was used for data processing. On the basis of the results of the survey, tables of relative (\%) and absolute (quantity) frequency, cross tables (multi-way tables) were created. Comparison of the results of the survey was carried out in MS Excel.

The questionnaire (http://goo.gl/forms/km3BgxVDEX) was prepared to conduct the research. All questionnaires are divided into three blocks. The 1st question pool is aimed at gathering general information about the respondent (university, faculty, age, sex), some experience in the use of social networks in everyday life and in education, time sharing in social networks between the different activities, etc. The 2nd question pool is aimed at evaluating pedagogical and psychological characteristics of learning in social networks on 12 criteria. The 3rd question pool is aimed at information gathering on the types and periodicity (frequency) of students' training activity in social networks.

The questionnaire was posted on open access and transferred to respondents through social networks, LMS Moodle and e-mail.

\section{Results}

$98 \%$ of respondents who took part in the survey actively use social networks in their daily lives. $95 \%$ of them use social networks for learning, and 5\% refrain from using them. Among the reasons for rejection, there are following: "We must learn how to use", "The interface is inconvenient for learning", "The use is time-consuming", "Traditional teaching methods are quite sufficient", "I use other tools for e-learning".

With the help of the question "What part of the time spent on social networks, you spend on learning, entertainment/ communication, search for useful information" inconsistent data had been received. Of course, specifics of time spending on social networks depend on the habits and lifestyle of the person. But we tried to determine the average value of the data: training - $24 \%$, entertainment and communication - $41 \%$, search for useful information $-28 \%$, other $-7 \%$. These data refute the widespread belief that students use social networks primarily for entertainment and that is why social networking is not an appropriate tool for training. The respondents' answers indicate that young people actively use social networks for academic pursuits and self-development.

As the result of these data, a hypothesis appeared. Students will spend less time on entertainment on social networks and more time on study, if teachers initiate interaction with them through social networks. To test the hypothesis, an experiment was conducted. During the semester, the students of Tomsk State University from three different groups 
(102 students) were suggested to interact with the teacher not only in the classroom and LMS, but also on the social network in a specially prepared community. Before and after the experiment, students were asked about how they spend their time on social networks. The survey results are presented in the table.

Table 1. Distribution of time in social networks

\begin{tabular}{lcc}
\hline & $\begin{array}{c}\text { Before the } \\
\text { experiment }\end{array}$ & $\begin{array}{c}\text { After the } \\
\text { experiment }\end{array}$ \\
\hline Education & $24 \%$ & $31 \%$ \\
Entertainment/communication & $41 \%$ & $33 \%$ \\
Search for useful information & $28 \%$ & $30 \%$ \\
Other & $7 \%$ & $6 \%$ \\
\hline
\end{tabular}

The data received confirmed our hypothesis about the possibility of switching the attention of students on social networks from entertainment to education. To do this, teachers need to begin active use of social media in the learning process.

The results of the responses of the main group of respondents (375 people) showed the ratio in time of different types of learning activities of students. $35 \%$ of their training time students spend in the classroom with a teacher, $22 \%$ - independent work with a variety of Web resources (search engines, forums, online libraries, e-books, blogs, wiki, etc.), $21 \%$ independent work without computers, $15 \%$ - learning through the use of social networks, $7 \%$ - by means of LMS. These data indicate the actual use of the blended learning model by students: $56 \%$ of study in the traditional form (classroom and independent work without ICT), 44\% of e-learning (different sites, social networks, LMS). But e-learning is based on the instruments of the personal learning environment (various web resources, social networks), rather than LMS. In addition, the use of social networks in learning does not seem excessive $(15 \%)$ in comparison with other forms of learning. Respondents in the survey responses also indicated the advantages and disadvantages of using social networking in the learning process.

Table 2. Advantages of social networks

\begin{tabular}{ll}
\hline Operational efficiency of communication & $18 \%$ \\
Habitual & $15 \%$ \\
Communication with others & $13 \%$ \\
Convenience & $9 \%$ \\
Mobile applications & $7 \%$ \\
Dialogueness & $4 \%$ \\
More information & $3 \%$ \\
Organization of academic activity & $3 \%$ \\
User-friendly interface & $3 \%$ \\
Upgrade & $1 \%$ \\
Availability at any time & $1 \%$ \\
Entertainment & $1 \%$ \\
\hline
\end{tabular}

Communication is an important factor for students, the leading categories in the advantages are "Operational efficiency of communication", "The ability to communicate with other participants," as well as "Convenience" and "Habitual system." 
Table 3. Disadvantages of social networks

\begin{tabular}{lc}
\hline Many distractions & $7 \%$ \\
Not much educational information & $1 \%$ \\
Everyone can be seen online & $1 \%$ \\
\hline
\end{tabular}

Students see the presence of distracting information from study, lack of proper training information and the necessity to be online that requires personal interaction as the main drawbacks.

Information about forms of students' learning shows that the majority of respondents regularly use social networks for the study and interaction with the participants of the educational process (teachers and groupmates).

Table 4. How students use social networks

\begin{tabular}{|c|c|c|c|c|c|c|c|c|}
\hline & $\begin{array}{l}\text { Viewing or } \\
\text { downloading } \\
\text { of learning } \\
\text { materials }\end{array}$ & $\begin{array}{l}\text { Making } \\
\text { of tasks }\end{array}$ & $\begin{array}{l}\text { Communication } \\
\text { with } \\
\text { groupmates }\end{array}$ & $\begin{array}{l}\text { Communication } \\
\text { with teachers }\end{array}$ & $\begin{array}{l}\text { Sharing } \\
\text { use of } \\
\text { learning } \\
\text { materials }\end{array}$ & $\begin{array}{l}\text { Doing } \\
\text { of } \\
\text { personal } \\
\text { tasks }\end{array}$ & $\begin{array}{l}\text { Doing } \\
\text { of } \\
\text { group } \\
\text { tasks }\end{array}$ & $\begin{array}{l}\text { Receiving } \\
\text { mark }\end{array}$ \\
\hline Every day & $28 \%$ & $24 \%$ & $70 \%$ & $19 \%$ & $20 \%$ & $12 \%$ & $9 \%$ & $4 \%$ \\
\hline $\begin{array}{l}\text { Once or } \\
\text { more every } \\
\text { week }\end{array}$ & $42 \%$ & $43 \%$ & $22 \%$ & $27 \%$ & $31 \%$ & $27 \%$ & $36 \%$ & $12 \%$ \\
\hline $\begin{array}{l}\text { Once or } \\
\text { more every } \\
\text { month }\end{array}$ & $15 \%$ & $14 \%$ & $3 \%$ & $21 \%$ & $20 \%$ & $17 \%$ & $27 \%$ & $8 \%$ \\
\hline $\begin{array}{l}\text { Once or } \\
\text { more every } \\
\text { semester }\end{array}$ & $4 \%$ & $9 \%$ & $2 \%$ & $16 \%$ & $12 \%$ & $13 \%$ & $17 \%$ & $8 \%$ \\
\hline Never & $11 \%$ & $10 \%$ & $3 \%$ & $17 \%$ & $17 \%$ & $31 \%$ & $11 \%$ & $67 \%$ \\
\hline
\end{tabular}

At the same time, the use of social networks is not typical to perform individual tasks, and receiving mark from the teacher.

\section{Discussion and conclusion}

How Russian students use social networks in education? The study partly provide an answer to this question. Most of the students use social networks in their daily lives (98\%). Therefore, for them, this is the most convenient platform for the organization of communication, including in the context of education. As the vast majority (95\%) involve social networks in their training, despite the fact that many of them $(51 \%)$ are available special tools of e-learning (LMS). Social networks are the de facto space for learning, and it's happening at the initiative of the students themselves. $24 \%$ of the time spent on the social network, students devote their studies. And if the teacher offers students interact via the network in the course, the students' attention more switches from entertainment to education. Thus, social networks can be an additional tool for learning and not interfere with it as many believe. At the same time we should not overestimate the influence of social networking in education. Despite their popularity among young people, students spend in them, only $15 \%$ of their study time. 
At the same time, LMS are less popular among students (7\%) than social networks. On the one hand this fact is related to the unavailability of LMS for respondents from some universities (49\%). On the other hand, social networks are more attractive for students on such important criteria as the efficiency of communication, familiarity and convenience of the system, the ability to connect via the mobile application. These are important features in LMS students feel very weak [7].

For further development of the research we aim to check the data collected in Russia using survey and interviewing of students and teachers from foreign universities. In our opinion comparison of students and teachers in their relation to the e-learning instruments in different universities and countries enable to examine the results by interaction of more respondents to the research, to define perspective directions of e-learning development taking into account opinions of its participants. Conclusions of this study will help us to understand and improve our use of LMS and SN tools in educational contexts. Our final goal is to adapt our teaching strategies to the educational needs of our students.

\section{References}

1. Feshchenko A., Mozhaeva G., \& Kulikov I. E-learning in the evaluation of students and teachers: lms or social networks? Procedia - Social and Behavioral Sciences, 152, 127 - 130., (2014).

2. Dabbagh, N., \& Kitsantas, A. Personal Learning Environments, social media, and selfregulated learning: A natural formula for connecting formal and informal learning. The Internet and Higher Education, 15(1), 3-8., (2012).

3. Bogdanov, E., Limpens, F., Li, N., El Helou, S., Salzmann, C., \& Gillet, D. A social media platform in higher education. In Global engineering education conference (educon), 2012 ieee (pp. 1-8). IEEE., (2012).

4. Meishar-Tal, H., Kurtz, G., \& Pieterse, E. Facebook groups as LMS: A case study. The International Review of Research in Open and Distance Learning,13(4), 33-48., (2012).

5. Mozhaeva G. Network interaction in distance education: Analysis of Russian experience. Procedia - Social and Behavioral Sciences, 152, 1124-1127., (2014).

6. Feshchenko, A. Social networks in education: the attitude of students and teachers. Triple Helix XII International Conference "The Triple Helix and Innovation-Based Economic Growth: New Frontiers and Solutions", Tomsk, Russia, September 11-13, 2014. Proceedings, 245-248., (2014).

7. Feshchenko A., Mozhaeva G., Kulikov I., \& Zilberman N. Prospects for the development of e-learning technologies. CSEDU 2015 - Proceedings of the 7th International Conference on Computer Supported Education, 1, 208-212., (2015). 